\title{
HOW FAR ALONG IS EURO ADOPTION IN THE CZECH REPUBLIC? BENEFITS FOR BUSINESSES STILL REMAIN
}

\author{
Helísek, $M$.
}

The objective of the paper is to assess the reasons for the current negative position of the Czech Government toward euro adoption and to find out whether the expected benefits of euro adoption for Czech companies still remain. The postponement of euro adoption in the Czech Republic has mainly been caused by the current problems of the euro area. The benefits arising from euro adoption are subject to the reduction of the exchange rate volatility and of the transaction costs, whereas they also depend on the degree of integration with the euro area. These benefits may still be expected - neither the financial crisis nor the economic recession has affected them. The integration of the Czech economy with the euro area is high and still growing. Therefore, euro adoption will lead to the stimulation of mutual trade of the Czech Republic and the euro area.

JEL Classification: F36, M16, M21

Keywords: euro; euro area enlargement; exchange rate volatility; transaction costs

\section{Introduction}

The key expected benefits arising from the replacement of the Czech koruna by the euro include the expansion of trade relations with the euro area countries - due to the elimination of the exchange rate risk. This expected benefit has been emphasized since the efforts for the euro adoption in the Czech Republic started. It is also stated in the first official strategic document relating to the euro adoption, specifically in the strategy for the accession to the euro area of 2003: "The domestic enterprise sector in particular will profit from the elimination of exchange rate risk vis-à-vis the euro-area countries, which are the Czech Republic's most important trading partners" (The Czech Republic's Euro-area Accession Strategy, p. 3). Another expected benefit of the single currency adoption is the reduction of certain transaction costs.

However, euro adoption in the Czech Republic is nowhere in sight. The first objective of this paper is to recall the ambitious efforts for an early accession to the euro area and to assess the reasons for the current negative position of the Czech Government toward euro adoption. Are the reasons on the part of the Czech economy or are these problems on the part of the euro area? The second goal is to find an answer to the question of whether or not the expected benefits of euro adoption still remain. Has the financial crises, together with the associated economic recession, led to changes, due to which euro adoption is no longer beneficial?

\section{Methods}

In order to achieve the objectives specified in the introduction, it is first necessary to describe the key documents of the Government of the Czech Republic and the associated practical measures that prepare the euro adoption. In order to assess the preparedness of the Czech economy for euro adoption, selected statistical macroeconomic data of the Czech Republic and the euro area are compared. With a view to assess the expected benefits arising from the replacement of the Czech koruna by a single currency, the empirical data collected from the statistical databases of the Czech Statistical Office and the Czech National Bank are analyzed. Furthermore, the results of several domestic and international studies are also utilized.

\section{Obligation to Adopt the Euro and Existing Preparations}

The obligation to replace the national currency with the euro, i.e. to take part in the third stage of the Economic and Monetary Union (EMU) arises for new Member States upon their accession to the European Union. Temporarily, these are the so-called "Member States with derogation", because they have not met the conditions necessary for the single currency adoption. The Czech Republic is one of these states. The requirements of international investors and international organizations for the Czech Government to specify its plans 
Table 1: Planned date for the accession to the euro area

\begin{tabular}{|c|c|c|}
\hline Country & Original date & New date * \\
\hline Bulgaria & $\begin{array}{l}\text { not determined (as soon as possible, after the Maastricht criteria } \\
\text { are met) }\end{array}$ & --- \\
\hline Czech Republic & 1.1.2010; annulled on 25.10 .2006 & not determined \\
\hline Latvia & 1.1.2008; annulled in spring of 2006 & 1.1.2014 \\
\hline Lithuania & $\begin{array}{l}\text { 1.1.2007; Commission did not recommend the euro introduction } \\
\text { (16.5.2006) }\end{array}$ & $\begin{array}{l}\text { at the earliest } \\
\text { possible date }\end{array}$ \\
\hline Hungary & 1.1.2010; annulled on 1.12.2006 & not determined \\
\hline Poland & 1.1.1012; annulled in the late 2009 & $\begin{array}{l}\text { as soon as possible after } \\
\text { fulfilling the entry conditions }\end{array}$ \\
\hline Romania & 2015 & --- \\
\hline Sweden & not determined (rejected in a referendum on 14.9.2003) & --- \\
\hline Great Britain, Denmark & permanent opt-out clause in third stage of EMU & -- \\
\hline
\end{tabular}

Sources: Commission of the EC: Reports on the Practical Preparations for the Future Enlargement of the Euro Area. 2004-2010. * Eleventh Report 2010, Accompanying document.

Notes: EMU = Economic and monetary union. Further reports (after 2010) are not published.

relating to the euro area accession started to appear prior to the accession of the Czech Republic to the EU, specifically since 2001 (Dyson, 2006, pp. 171 - 172).

Let us recall the plans of the Czech Government relating to euro adoption:

- The Czech Republic's Euro Area Accession Strategy (of September 2003) specifies the "period of 2009-2010", which was later clarified in the Institutional Arrangements for Introduction of the Euro (23 November 2005) to a "working date" of 1 January 2010.

- On 25 October 2006, the Government of the Czech Republic decided not to attempt the accession to the exchange rate mechanism ERM II in 2007, which resulted in the annulment of the original plan to enter the euro area in 2010. A new date has not been set.

- The Czech Republic's Updated Euro Area Accession Strategy (of August 2007) confirmed both the annulment of the original date (2010) as well as the absence of a new specific date for the planned accession to the euro area. The date of euro adoption will be derived from the resolution of "problematic areas" of the Czech economy, i.e. mainly public finance reform and flexibility of the economy, especially of the labor markets.

- The annually published Assessments of the Fulfillment of the Maastricht Convergence Criteria have included the same recommendation for the Government of the Czech Republic since 2006 - i.e. not to set a date for euro area accession.
At the same time, the position of the Czech Republic relating to the postponement of the euro adoption is not exceptional by any means. Most new Member States of the EU that are not members of the euro area are still to set a date for euro adoption (see Table 1).

The specification of the euro area accession date falls within the competence of each Member State, depending on its readiness. Many key measures that prepare the euro adoption have already been adopted in the Czech Republic:

- The Czech Republic's Euro Area Accession Strategy and The Czech Republic's Updated Euro Area Accession Strategy (2003, 2007);

- The Government adopted the Institutional Arrangements for Introduction of the Euro in the Czech Republic (November 2005), which include the appointment of the National Coordination Group and of the National Coordinator;

- In October 2006, the Government opted for the "Big Bang Scenario" for the euro adoption in the Czech Republic, i.e. single-step introduction of cash and noncash euro;

- In April 2007, the Government approved the National Euro Changeover Plan for the Czech Republic (with annual Reports that represent amendments of the Plan);

- General Act on Introduction of the Euro in the Czech Republic - basic principles - was adopted (2008);

- Annual Assessments of the Fulfillment of the Maastricht Convergence Criteria and the Degree of 
Economic Alignment of the Czech Republic with the Euro Area, prepared by the CNB and the Ministry of Finance of the Czech Republic;

- Furthermore, the Government prepares an annual Convergence Program of the Czech Republic, which is drafted by the Ministry of Finance of the Czech Republic and which mainly assesses the condition of the public finances;

- A new Act on the CNB was prepared but vetoed by the President of the Czech Republic;

- In the period of 2007 - 2009, the National Coordination Group published the total of seven methodological materials (e.g. rules for converting and rounding off financial amounts, procedures for dual quotations, preparation of legal environment, preparation of the financial sector, communication strategy, and others).

The existing measures resulted in the praise of the European Commission in July 2007. The Czech Republic was marked as a good example of timely preparation even without a set target date (Commission of the EC, Fifth Report, 2007, p. 10).

\section{Preparedness of the Czech Economy for the Euro Adoption}

The economic preparedness of the Czech Republic for the euro area accession may be assessed using the nominal and real convergence criteria.

The nominal convergence criteria are represented by the well-known Maastricht criteria. These criteria are assessed, every two years, in the Convergence Reports of the European Commission and European Central Bank. The criteria are assessed as follows in the European Commission report of May 2012 (European Commission, 2012):
- The price stability criterion has been met. The inflation measured by the HICP amounted to $2.7 \%$ during the reference period (April 2011 - March 2012), compared to the reference value of $3.1 \%$.

- Criterion relating to the sustainability of the public finances has not been met due to the deficit amount in 2011 , specifically $3.1 \%$ of GDP, compared to the requirement of $3.0 \%$. The total public debt does not amount to the maximum permitted level of $60 \%$ (according to the Ministry of Finance, it amounted to $40.8 \%$ of GDP in 2011).

- Criterion of the exchange rate stability has not been met due to the fact that the Czech koruna does not take part in ERM II; the EC solely states that there is a slight appreciation of the exchange rate in the two-year period in question. However, if we were to simulate the participation of the Czech koruna in ERM II, relying on the methodological approach of the ECB and excluding the abnormal financial crisis period, the criterion would be unambiguously met (Helísek, 2011).

- Criterion relating to the convergence of long-term interest rates has been met $(3.5 \%$ compared to the reference value of $5.8 \%$ ).

We will add the 2012 development estimates as well as the outlook for the period of 2013 - 2014 to the above mentioned indicators (Assessment, 2012). The inflation criterion would not be met in 2012, namely due to an increase in the reduced VAT rate at the beginning of 2012. However, according to the prognosis of the Ministry of Finance and of the Czech National Bank, it should be met without any problems in the following years. The public finance deficit for 2012 is estimated at a considerably higher level - specifically at $5 \%$. This is mainly caused by the church compensations in

Table 2: Real convergence one year before joining the euro area (in $\%$ of euro area 17 )

\begin{tabular}{|l|c|c|c|c|c|c|}
\hline & Slovakia & Portugal & Greece & \multicolumn{3}{|c|}{ Czech Republic } \\
\cline { 5 - 8 } & $\mathbf{2 0 0 8}$ & $\mathbf{1 9 9 8}$ & $\mathbf{2 0 0 0}$ & $\mathbf{2 0 0 9}$ & $\mathbf{2 0 1 0}$ & $\mathbf{2 0 1 1}$ \\
\hline Economic level & 67.0 & 70.0 & 75.0 & 75.2 & 74.1 & 74.1 \\
\hline Price level & 67.6 & 82.3 & 84.7 & 69.2 & 72.2 & 73.6 \\
\hline
\end{tabular}

Source: http://epp.eurostat.ec.europa.eu - Statistics - Economy and Finance:

National accounts - GDP per Capita (http://epp.eurostat.ec.europa.eu/tgm/table. do?tab=table\&init=1\&language $=$ en \&pcode=tec00114\&plugin=1)

Purchasing Power Parities - Comparative Price Levels (http://epp.eurostat.ec.europa.eu/tgm/table. do?tab=table\&init=1\&plugin=1\&language $=$ en \&pcode $=$ tec00120)

Own calculation. January 2013. 
the amount of CZK 59 billion. However, the fiscal strategy of the Government aims to reduce this deficit to $2.9 \%$ in 2013 (and 2.7\% in 2014), under the influence of recommendations specified in the Procedure for excessive deficit maintained by the Czech Republic since 2 December 2009. The deficit reduction is also expressly specified in the Policy Statement of the Government of the Czech Republic of August 2010.

The Czech Republic has also been recording positive results in the area of real convergence, in terms of the economic level indicator (see Table 2). It thereby meets the unofficially proposed criterion of GDP per capita at the level of $70 \%$ of the Euro area average (Dabrowski - Rostowski, 2006, p. 6). The results in the area of price convergence are lagging behind.

\section{Barriers to Entering the Euro Area}

In order to assess the barriers, which are used to substantiate the negative position of the Government for an early adoption of the euro, we will use the report entitled Assessments of the Fulfillment of the Maastricht Convergence Criteria and the Degree of Economic Alignment of the Czech Republic with the Euro Area, which is jointly presented to the Government by the Ministry of Finance of the Czech Republic and the Czech National Bank at the end of each year (Assessments, 2009 - 2012). The aforementioned negative position of the current Government is also apparent by the fact that the Policy Statement of the Government of the Czech Republic (4 August 2010) that has 41 pages in total does not mention a single word about the perspective of the euro introduction.

The report of 2009 mainly mentions domestic economic problems, such as the increasing public finance deficit, higher volatility of the Czech koruna exchange rate, and continuing low flexibility of the labor markets (namely the unsatisfactory qualification of people unemployed on a long-term basis, low flexibility of real wages, high regional differences in the unemployment rate, and others).

The reports of 2010 - 2011 also mentioned the problems of the euro area. Specifically, it concerned the fiscal problems of many euro area states, which leads to uncertainty on the international financial markets, concerns of investors, potential setbacks in the short-term capital flows, and threat to stability of the Czech koruna, if it were to be included in ERM II.

The report of 2012 contains certain developments, as it notes the ongoing crucial changes in the institutional arrangement of the monetary union in reaction to the debt problems of certain euro area member states. The accession to the euro area is likely to be subject to the participation in the newly developing institutions (such as the fiscal union / banking union) and stability mechanisms (such as the European Stability Mechanism). All this generates new and formerly unexpected liabilities and costs, which (expressed implicitly) is a different situation from the period of accession to the European Union in 2004. These changes (only expressed implicitly, once again) thus impeach the obligation to adopt the euro.

\section{Benefits from the Euro Adoption for Czech Companies}

The monetary integration theory (see, for example, De Grauwe, 2007, Begg et al., 2003, Baldwin and Wyplosz, 2006) generally comes to a conclusion on the stimulation of international trade in an acceding country with the existing members of a monetary union. This is achieved as a result of the following two changes, for which their quantification is also specified:

1) The exchange rate risk and the costs associated the- rewith disappear. In case of the existence of the independent Czech koruna, with the CZK/EUR and $\mathrm{CZK} / \mathrm{USD}$ exchange rates, the exchange rate volatility (expressed by a weighted variable coefficient) is 2.1 times higher than in the case of the hypothetical replacement of Czech koruna with the euro, with the EUR/EUR and USD/EUR exchange rates, i.e. in case of a simplification that the remaining international trade takes place in USD (Helísek, 2012).

2) Certain transaction costs associated with the management of foreign currencies cease to exist - e.g. costs of the foreign currency conversions, higher costs of the payment system when using foreign currencies, costs associated with the maintenance of additional accounts (i.e. foreign currency accounts), costs arising from more complex bookkeeping when using foreign currencies, etc. These costs are estimated at $0.28 \%$ of GDP in the Czech Republic (Lacina et al., 2007, p. 81).

How is the overall contribution of a single currency to the development of mutual trade of the euro area members quantified? According to the European Commission study EMU@10 (European Commission, 2008, p. 4), the mutual trade of the euro area Member States has increased from one fourth to one third of GDP in the past 10 years. One half of this increase is attributed to the effect of exchange rate risk elimination and lower costs.

Another fact - however, not a general one but rather a fact specific for the Czech Republic - is stopping the trend of the Czech koruna to euro appreciation, which has been undermining the competitiveness of Czech exporters on a long-term basis, while reducing the price of foreign products and services on the Czech market. This trend is shown in Figure 1. 
Figure 1: Exchange rate CZK/EUR development

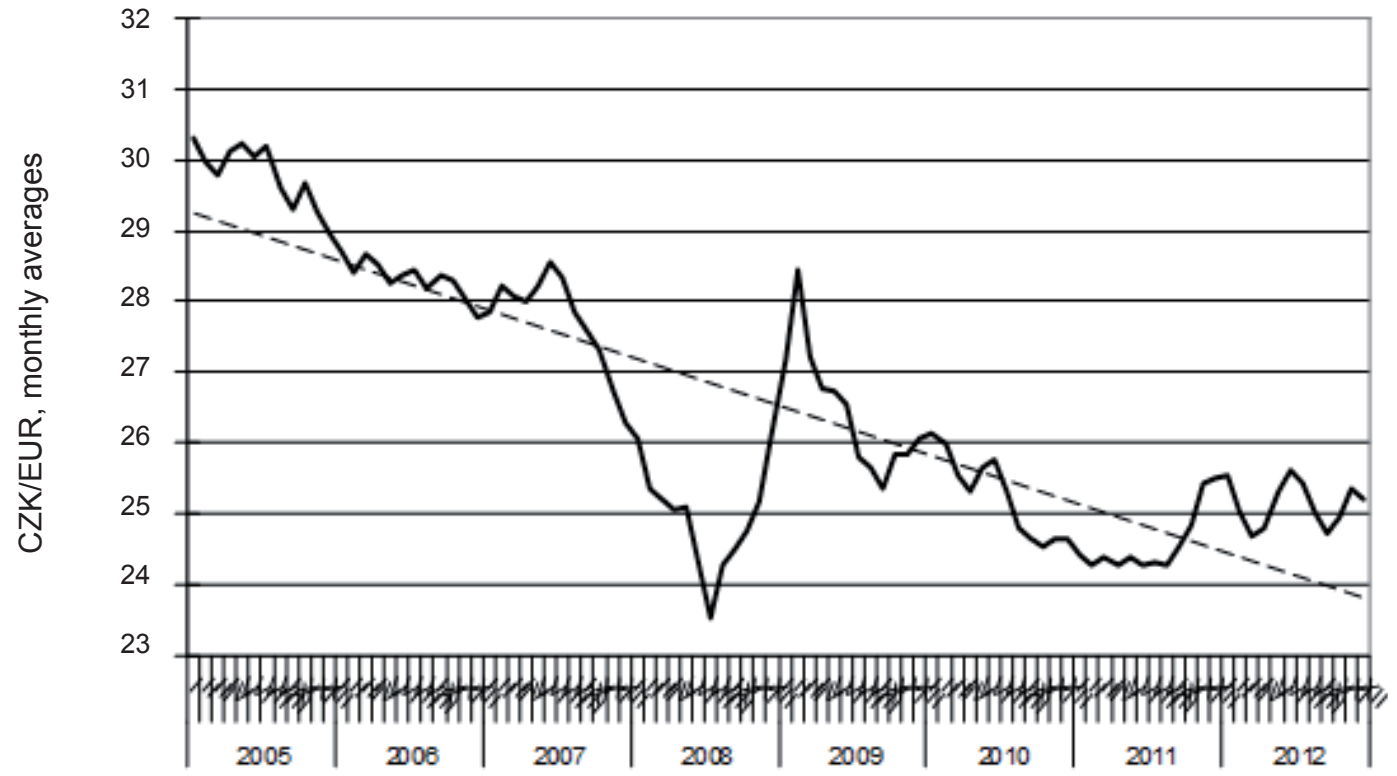

Source:

http://www.cnb.cz/cs/financni_trhy/devizovy_trh/kurzy_devizoveho_trhu/prumerne_mena.jsp?mena=EUR

Own preparation.

In the period of $2005-2012$, the average monthly appreciation amounted to $0.06 \mathrm{CZK} / \mathrm{EUR}$. In other words, this means that the price of CZK 100 increased from EUR 3.41 to EUR 4.20 in the trend in the period under review.

\section{Interconnection of the Czech Economy With the Euro Area}

The benefits arising from the replacement of a national currency by a monetary union single currency will be high for the corporate segment, in case the integration of the given economy with the economies of the monetary union member states is high (or increasing). The development of the integration of the Czech economy with the euro area states is characterized by Figure 2.

The data from Figure 2 demonstrate that the economic integration of the Czech Republic with the euro area is slightly increasing. This development is mainly promoted by euro area expansion, namely by the Slovak Republic (the share of Slovakia in the Czech trade amounted to $8.2 \%$ in 2011).

\section{Managerial Implications}

The business segment (with the exception of banks) - and especially exporters - is largely in support of a prompt introduction of the euro in the Czech Republic. The competitiveness of Czech exporters would be promoted in case the exchange rate risks in the trade with the euro area were to disappear (it covers nearly $60 \%$ of our foreign trade turnover). Furthermore, the disappearance of the long-term appreciation of the $\mathrm{CZK} / \mathrm{EUR}$ exchange rate would also have a positive effect.

The experience of exporters is represented by the opinion of the largest Czech exporter, i.e. the car producer Škoda Auto in Mladá Boleslav: "The current value of the Czech koruna is not proportionate to the strength of our economy. It is pulled upwards by financial market speculations. The appreciations have a negative impact on exporters; in case of Škoda Auto the exchange rate appreciation by CZK 1 to the EUR results in a loss of approximately 1 billion CZK" (Špicar, 2011).

The standpoint of companies has also been cogently expressed by the National Coordinator for euro adoption in the Czech Republic: "The extent of the sacrifice arising from the loss of a national currency should primarily be inquired with the Czech businesses. [...] They say that the existence of a national currency constitutes a competitive disadvantage for them on the EU market. [...] We should listen to the voice of the professionals, while slightly discounting the macroeconomists, who 'excavate evidence' on the disadvantages of the euro for the Czech economy from not so robust data" (Dědek, 2009, p. 41). 
Figure 2: Interconnection of the Czech Republic with the euro area

Export - import (gods and services)

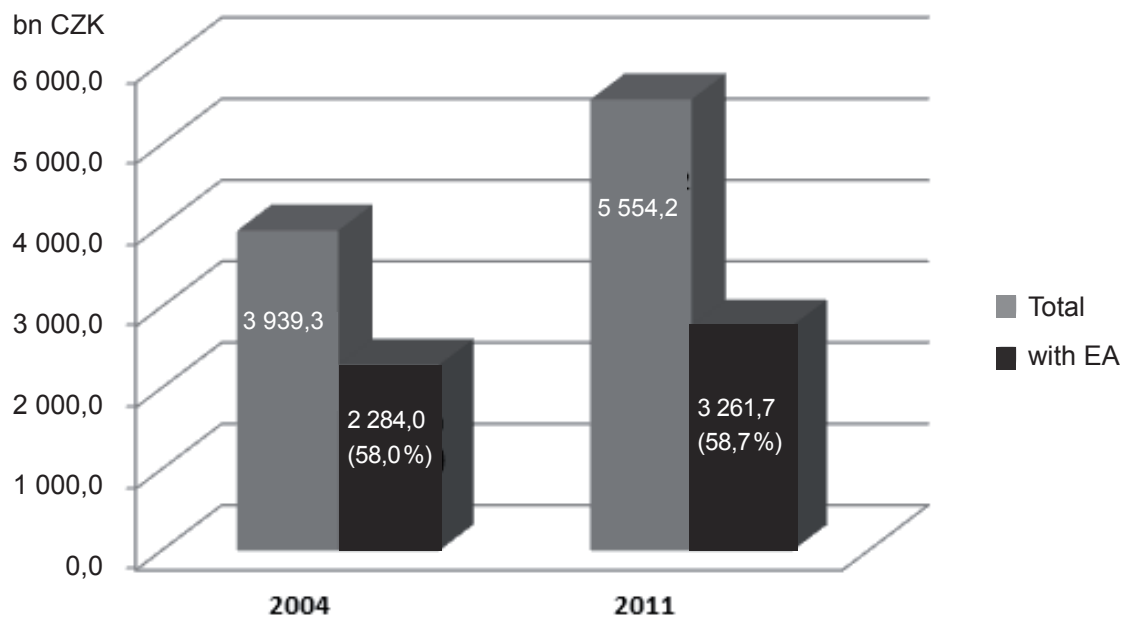

FDI in Czech Republic (stock at end of year)

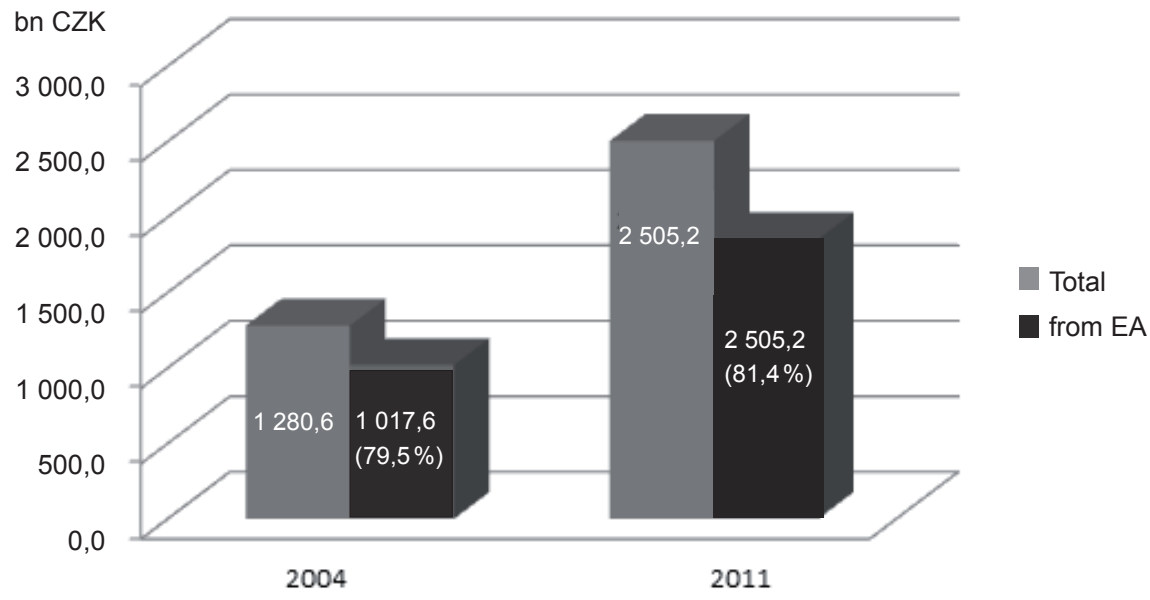

Sources: Current account: http://www.cnb.cz/cs/statistika/platebni_bilance_stat/publikace_pb/bezny_ucet_pb_ tc/index.html

FDI: http://www.cnb.cz/cs/statistika/platebni_bilance_stat/pzi/index.html

Own calculations.

Notes: * community principle. EA = euro area in composition according to the current situation in these years (i. e. 12 members and 17 members). Stock of FDI at the end of 2011 was calculated by adding the flows quantites from 2011 to the stock of FDI at the end of 2010.

\section{Conclusion}

The Czech economy is strongly integrated with the euro area, whereas the integration has been slightly increasing over time. The financial crisis and the economic recession have not affected this development in any way. Our business relations would be more stable in case of the euro adoption than in case of the Czech koruna's existence.
Furthermore, the exchange rate of the Czech koruna shows a long-term appreciation trend against the euro, which undermines the competitiveness of Czech exporters. The increasing integration of the Czech economy with the economy of the euro area and the need of a stable exchange rate remain the key reason for the single currency adoption. 
The economic problems of the Czech Republic do not represent the main barrier to an early adoption of the euro, because the nominal/real convergence criteria have either been met or their fulfillment is realistic in the foreseeable future. The cautious or even negative position of Czech political representation in respect of the euro has been caused by the constitution of new institutions within the euro area, the acceptance of which is associated with euro adoption and which result in additional liabilities and costs.

\section{References}

Czech National Bank (2012). Assessment of the Fulfilment of the Maastricht Convergence Criteria and the Degree of Economic Alignment of the Czech Economy With the Euro Area. A joint document of the Ministry of Finance of the Czech Republic and the Czech National Bank. 2009 - 2012. (accessed January 30, 2013), [available at http:// www.zavedenieura.cz/cps/rde/xbcr/euro/Assessment Maastricht_Criteria_2012_EN_pdf.pdf].

Baldwin, R., Wyplosz, C. (2006). The Economics of European Integration. 2nd Ed. McGraw-Hill International UK Limited.

Begg, D. et al. (2003). The consequences of saying no. An independent report into the economic consequences of the UK saying no to the euro. May 2003, (accessed March 24, 2004), [available at http://faculty.london.edu/rportes/ research/BeggCommissionReport.pdf].

The Czech Republic's Euro-area Accession Strategy. Joint Document of the Czech Government and the Czech National Bank. 2003. (accessed February 24, 2011), [available at http://www.zavedenieura.cz/cps/rde/xbcr/euro/ eurostrategy_CR_en_2003_pdf.pdf].

Commission of the EC (2010). Reports on the Practical Preparations for the Future Enlargement of the Euro Area, (accessed March 4, 2011), [available at http://ec.europa.eu/ economy_finance/articles/euro/2010-11-report-preparations-enlargement-euro-area_en.htm].

Dabrowski M., Rostowski, J. (2006). The Eastern Enlargement of the Eurozone. Dordrecht: Springer.

Dědek, O. (2009). Skončeme s kurzovým gamblerstvím, Ekonom, No. 34, p. 41.

De Grauwe, P. (2007). Economics of Monetary Union. Seventh Ed. Oxford: Oxford University Press.

Dyson, K. (ed.). (2006). Enlarging the Euro Area. External Empowerment and Domestic Transformation in East Central Europe. Oxford: Oxford University Press.
European Commission (2008).EMU@10: successes and challenges after 10 years of Economic and Monetary Union. May 7, 2008, (accessed October 1, 2010), [available at http://ec.europa.eu/economy_finance/emu10/emu10report_en.pdf].

European Commission (2012). Convergence Report. 2012, (accessed January 30, 2013), [available at http://ec.europa.eu/economy_finance/publications/ european_economy/2012/convergence-report_en.htm].

Government of the Czech Republic (2010). Policy Statement from the Government of the Czech Republic. 4th August 2010, (accessed December 24, 2010), [available at http://www. vlada.cz/assets/media-centrum/dulezite-dokumenty/PolicyStatement-from-the-Government-of-the-Czech-Republic.pdf].

Helísek, M. (2011). Impacts of Financial Crisis on the Euro Introduction in the Czech Republic. ACTA VŠFS, 5 (3): 220-240, (accessed January 24, 2012), [available at http:// www.vsfs.cz/periodika/acta-2011-03.pdf].

Helísek, M. (2012). Potential Impact of the Euro Adoption in the Czech Republic on Relations with the Euro Area. EuroEconomica, 31 (4): 87-97, (accessed January 30, 2013), [available at http://journals.univ-danubius.ro/index. php/euroeconomica/article/view/1490].

Lacina, L. et al. (2007). Studie vlivu zavedení eura na ekonomiku $\check{C} R$. Ministerstvo financí České republiky, (accessed October 1, 2010), [available at http://www.mfcr.cz/cps/ $\mathrm{rde} / \mathrm{xbcr} / \mathrm{mfcr} /$ Studie NKS_final_upravena_po_opnenture_31_08_20081.pdf].

Špicar, R. (2011). Problém zvaný silná koruna, Hospodářské noviny, January 19, (accessed February 20, 2011), [available at http://byznys.ihned.cz/c1-49507610-firmy-uzse-naucily-zit-se-silnou-korunou-presto-vyvoj-sleduji-sobavami].

\section{Acknowledgment}

The research was supported by funds from Specific University Research that has been provided to University of Finance and Administration in 2013.

\footnotetext{
Author

Assoc. Prof. Mojmír Helísek

Department of Economics and International Relations University of Finance and Administration Estonská 500, 10100 Prague 10, Czech Republic mojmir.helisek@vsfs.cz
} 